\title{
Kemampuan Tim Pengembang Kurikulum Merancang Kegiatan Pembelajaran dan Penilaian Yang Mengembangkan Keterampilan Berpikir Kompleks (Suatu survai terhadap TPK di 4 kabupaten)
}

\author{
Mutiara O. Panjaitan \\ Pusat Kurikulum dan Perbukuan, Balitbang Kemdiknas \\ Email: mutiara_op@yahoo.com
}

\begin{abstract}
Abstrak: Tujuan penelitian dimaksudkan untuk memperoleh informasi tentang kemampuan TPK di empat kabupaten dalam merancang kegiatan pembelajaran dan penilaian bermuatan keterampilan berpikir kompleks yang meliputi berpikir kritis, pemecahan masalah, dan berpikir kreatif. Hasil penelitian menunjukkan bahwa berdasarkan hasil analisis dengan menggunakan Tabel The Cognitive Process Dimension dan Gubbin's Matrix of Thinking Skills, diketahui hanya $24.58 \%$ TPK yang mampu merancang kegiatan pembelajaran dan penilaian bermuatan keterampilan berpikir kompleks, dan dari jumlah tersebut hanya $31 \%$ yang mampu merancang tugas berpikir kreatif.
\end{abstract}

Kata kunci: TPK, kegiatan pembelajaran dan penilaian, dan berpikir kompleks.

\begin{abstract}
The objective of research is to obtain the information about the ability of Curriculum Development Team (TPK) of districts in designing learning activities and assessments contain complex thinking skills that include critical thinking, problem solving, and creative thinking. Based on the results of analysis using the Table of The Cognitive Process Dimension and Gubbin's Matrix of Thinking Skills, known that only $24.58 \%$ TPK capable of designing learning tasks and assessments containing complex thinking skills, and of that number only $31 \%$ are able to design a creative thinking task.
\end{abstract}

Keywords: TPK, evaluation and teaching learning process, complex thinking

\section{Pendahuluan}

Peningkatan mutu pendidikan terus-menerus diupayakan oleh pemerintah, sehingga bangsa Indonesia memiliki kemampuan kompetitif dengan bangsa-bangsa lain. Salah satu upaya tersebut yaitu desentralisasi penyelenggaraan pendidikan di mana penyusunan kurikulum menjadi tanggung jawab setiap satuan pendidikan. Pengembangan kurikulum oleh satuan pendidikan dilakukan dengan mengacu pada standar nasional pendidikan dalam rangka mewujudkan tujuan pendidikan nasional, yaitu mengembangkan potensi peserta didik agar menjadi manusia yang beriman dan bertakwa kepada Tuhan Yang Maha Esa, berakhlak mulia, sehat, berilmu, cakap, kreatif, mandiri, dan menjadi warga negara yang demokratis serta bertanggung jawab (UURI Nomor 20/2003).

Upaya lainnya yaitu membenahi proses pembelajaran dengan memberi rambu-rambu bagi pelaksanaan proses pembelajaran seperti ter- tuang dalam Peraturan Pemerintah (PP No. 19/ 2005) dan Peraturan Menteri (Permen No. 41/ 2007), bahwa untuk menghasilkan Iulusan yang bermutu, proses pembelajaran untuk setiap mata pelajaran harus fleksibel, bervariasi, dan memenuhi standar. Proses pembelajaran pada satuan pendidikan dasar dan menengah harus interaktif, inspiratif, menyenangkan, menantang, dan memotivasi peserta didik untuk berpartisipasi aktif serta memberikan ruang yang cukup bagi prakarsa, kreativitas, dan kemandirian sesuai dengan minat, bakat, dan perkembangan fisik serta psikologis peserta didik.

Rambu-rambu tersebut menghendaki keterlibatan peserta didik secara aktif, baik fisik maupun mental dalam proses pembelajaran. Peserta didik diberi kesempatan untuk mengungkapkan gagasan, pendapat, dan melakukan percobaan. Mereka diberi banyak kesempatan untuk bekerja, berbuat, dan menghasilkan berbagai karya, berupa karya seni, puisi, lagu, cerita fiksi dan 
nonfiksi, tarian, grafik, alternatif pemecahan suatu masalah, model tiga dimensi, laporan pengamatan, dan Iain-lain. Melalui karya-karya tersebut, daya kreasi dan daya cipta peserta didik dapat berkembang secara optimal. Pemberian tugastugas yang menantang mendorong dan membangun kemampuan-kemampuan unggul anak lainnya, seperti mencari dan mengolah informasi, menemukan alternatif pemecahan masalah, mengambil keputusan, berpikir kritis. Kemampuan-kemampuan unggul ini disebut dengan keterampilan berpikir kompleks. Keterlibatan peserta didik secara aktif dalam proses pembelajaran memberi sumbangan sangat besar untuk membangun dan mengembangkan prakarsa dan kreativitas peserta didik, yang pada akhirnya mampu menyiapkan lulusan untuk hidup dalam masyarakat secara mandiri, cerdas, dan kompetitif. Harapan ini sejalan dengan Instruksi Presiden Nomor 6, Tahun 2009 tentang Pengembangan Ekonomi Kreatif, yang menetapkan sasaran pertama yakni Insan kreatif dengan pola pikir dan moodset kreatif.

Pada dasarnya setiap anak lahir dengan bakat kreatif. Lingkungan anak amat berpengaruh pada keberhasilan pengembangan kreativitasnya, baik di lingkungan keluarga, sekolah, maupun masyarakat. Apabila bakat kreatif ini tidak diasah dan dipupuk, tidak akan pernah berkembang dan pada akhirnya menjadi bakat yang terpendam yang tidak pernah terwujudkan. Dalam dunia pendidikan bakat kreatif dikembangkan melalui proses pembelajaran yang mengaktifkan mental dan fisik anak, seperti melalui tugas-tugas yang memuat kemampuan berpikir kompleks. Untuk itu diperlukan guru yang mampu memberikan keteladanan, membangun kemauan, dan mengembangkan potensi dan kreativitas peserta didik, seperti yang dipersyaratkan pada Peraturan Menteri Pendidikan Nomor 41/2007.

Menurut peraturan perundang-undangan yang berlaku, pengembangan kurikulum diserahkan pada satuan pendidikan dengan mengacu pada standar nasional pendidikan. Menurut Surat Edaran Menteri Pendidikan Nasional Nomor 33/ MPN/SE/2007 tanggal 13 Februari 2007, dalam pengembangan kurikulum satuan pendidikan dasar dan menengah mendapat pelatihan dan pembinaan secara terus menerus dari tim pengembang kurikulum (TPK). Salah satu tugas TPK adalah menyediakan layanan dan konsultasi kurikulum dan pembelajaran bagi pihak yang membutuhkan (Puskur, 2007). Bila dicermati, masih banyak kurikulum sekolah yang memuat kegiatan pembelajaran dan penilaian bermuatan keterampilan berpikir rendah atau sederhana. Hal ini dapat diketahui dari KTSP peserta yang penulis peroleh ketika melakukan bantuan teknis di beberapa kabupaten/kota. Sebagai contoh, pada silabus beberapa mata pelajaran dari beberapa kabupaten ditemukan kegiatan pembelajaran, seperti: "Siswa memberi contoh jenis-jenis teknologi transportasi pada masa lalu dan masa kini (kelas 4); guru menjelaskan tentang perbedaan jenis kelamin (kelas 1); siswa menyebutkan macam organ penyusun sistem reproduksi pada manusia (kelas 9); siswa menyebutkan contoh besaran pokok dan besaran turunan (Fisika kelas 10). Tentu kondisi ini perlu dipertanyakan. Mungkin saja TPK sendiri belum mampu merancang kegiatan pembelajaran dan penilaian yang bermuatan keterampilan berpikir kompleks. Oleh karena itu, dipandang perlu untuk mengetahui kemampuan TPK dalam merancang kegiatan pembelajaran dan penilaian yang mampu membangun dan mengembangkan keterampilan berpikir kompleks anak.

Permasalahan yang dihadapi yaitu Bagaimana kemampuan TPK kabupaten dalam merancang kegiatan pembelajaran dan penilaian yang bermuatan keterampilan berpikir kompleks, dalam hal ini berpikir kritis, pemecahan masalah, dan berpikir kreatif. Tujuan penelitian dimaksudkan untuk memperoleh informasi tentang kemampuan TPK kabupaten dalam merancang kegiatan pembelajaran dan penilaian bermuatan keterampilan berpikir kompleks yang meliputi berpikir kritis, pemecahan masalah, dan berpikir kreatif. Informasi yang diperoleh dapat dijadikan masukan/rekomendasi bagi berbagai pihak dalam melaksanakan bimbingan teknis untuk TPK provinsi dan TPK kabupaten/kota, sehingga mampu membantu satuan pendidikan dalam merancang proses pembelajaran penilaian yang bermutu. 


\section{Kajian Literatur}

\section{Pengertian Tim Pengembang Kurikulum}

Menurut Surat Edaran Menteri Pendidikan Nasional Nomor 33/MPN/SE/2007 tanggal 13 Februari 2007, dinyatakan agar di setiap provinsi dan kabupaten/ kota dibentuk tim sosialisasi KTSP atau Tim Pengembang Kurikulum yang bertugas melakukan sosialisasi KTSP dan melatih serta membina secara terus menerus pengembangan KTSP oleh satuan pendidikan. Surat edaran ini ditujukan kepada semua pimpinan Unit Utama di lingkungan Depdiknas, Gubernur, dan Bupati/Walikota.

Tim Pengembang Kurikulum (TPK) merupakan kelompok kerja non struktural yang berfungsi membantu Dinas Pendidikan dalam pengembangan kurikulum. TPK di tingkat provinsi dibentuk dan ditetapkan dengan surat keputusan gubernur, sedangkan TPK di tingkat kabupaten/ kota dibentuk dan ditetapkan dengan surat keputusan bupati/walikota.

Berdasarkan Model Jaringan Kurikulum (Puskur, 2007), TPK mempunyai peranan sebagai pendamping atau fasilitator, mediator, dan inovator. Sebagai pendamping atau fasilitator, TPK berperan memberikan bantuan teknis kepada satuan pendidikan mengenai penyusunan dan penyempurnaan Kurikulum Tingkat Satuan Pendidikan di berbagai jenis dan jenjang pendidikan, implementasi, monitoring, evaluasi, dan supervisi klinis. Sebagai mediator, TPK berperan membantu menyosialisasikan berbagai kebijakan tentang kurikulum dari pemerintah pusat ke pemerintah daerah dan lembagalembaga penyelenggara pendidikan. Sebagai inovator, TPK berperan mengembangkan, mengkaji, dan mengembangkan model pengembangan kurikulum dan pembelajaran yang sesuai karakteristik, kebutuhan dan per-kembangan daerah/sekolah. Dalam membantu tugas Dinas Pendidikan, TPK mempunyai tugas, di antaranya: a) memberikan pelatihan pengembangan kurikulum di daerah dan lembaga lain; b) menyediakan layanan dan konsultasi kurikulum dan pembelajaran bagi pihak yang membutuhkan; c) menyosialisasikan kebijakan kurikulum; dan c) memberdayakan satuan pendidikan.

Adapun tugas TPK kabupaten/kota yaitu: 1) melakukan sosialisasi Permendiknas Nomor 22 Tahun 2006 dan Permendiknas Nomor 23 Tahun
2006 kepada seluruh satuan pendidikan dasar dan menengah di wilayah kabupaten/kota; dan 2) melatih dan membina secara terus menerus dalam pengembangan KTSP kepada satuan pendidikan dasar dan menengah di wilayah kabupaten/kota (SE Mendiknas No. 33/MPN/SE/ 2007).

Menurut Surat Edaran Mendiknas tersebut di atas unsur-unsur TPK di kabupaten/kota terdiri atas tenaga pendidik (guru) dan tenaga kependidikan di kabupaten/kota tersebut yang memiliki kemampuan untuk menyusun KTSP dan menyosialisasikan kepada satuan pendidikan dasar dan menengah di wilayah kabupaten/kota. Seseorang yang akan menjadi TPK harus melalui seleksi yang dilakukan oleh dinas pendidikan kabupaten/kota.

Dalam model jaringan kurikulum (Puskur, 2007) unsur-unsur TPK meliputi: Dinas Pendidikan, Guru, Kepala Sekolah, Pengawas Sekolah, Perguruan Tinggi, LPMP, dan Dewan Pendidikan. Unsur guru mencakup guru SD (kelas rendah, kelas tinggi), guru mata pelajaran (SMP, SMA, SMK), dan guru PLB. Dalam perjalanannya personal TPK juga mencakup PAUD, sehingga dalam berbagai kegiatan bantuan teknis profesional unsur PAUD juga disertakan sebagai TPK. Kenyataannya, di banyak daerah unsur TPK umumnya guru, kepala sekolah, dan pengawas sekolah.

Melihat peranan dan tugas TPK di atas, sebagai TPK, walaupun mereka berasal dari satuan pendidikan yang berbeda, mereka harus mampu memberikan layanan dan konsultasi kurikulum dan pembelajaran bagi satuan pendidikan yang membutuhkan; mereka harus mampu melakukan pendampingan kepada satuan pendidikan dalam pengembangan kurikulum dan pembelajaran serta implementasinya, melakukan supervisi klinis; mereka harus mampu memberikan pelatihan pengembangan kurikulum dan pembelajaran di berbagai jenis dan jenjang pendidikan.

Karena itu, pada kegiatan bantuan teknis profesional dan atau kegiatan-kegiatan pelatihan sejenis yang dilakukan oleh pusat, mereka mendapat materi pelatihan yang sama; tugas yang mereka lakukan sama namun substansi disesuaikan dengan jenis dan jenjang satuan pendidikan di mana mereka bekerja. Hal ini memungkinkan TPK yang bekerja di satuan 
pendidikan, misalnya SMK akan mampu melakukan pendampingan kepada satuan pendidikan dengan jenis dan jenjang berbeda. Dengan demikian, TPK yang berasal dari jenis dan jenjang satuan pendidikan yang berbeda diharapkan memiliki pengetahuan dan keterampilan yang sama sesuai tugas dan peran mereka seperti yang diuraikan di atas.

\section{Pengertian Keterampilan Berpikir Kompleks}

Keterampilan berpikir kompleks adalah jenis pemahaman yang memerlukan berpikir mendasar (basic thinking) dan mempunyai ciri-ciri menuntut berbagai kemungkinan jawaban, penilaian dari orang yang berpartisipasi, dan penempatan makna pada suatu situasi. Jenis keterampilan berpikir kompleks termasuk berpikir kritis, berpikir kreatif, dan memecahkan masalah. Berpikir Kritis bercirikan analisis yang dilakukan dengan hati hati, mengandung argumentasi, penggunaan kriteria yang objektif, dan evaluasi data. Pemecahan Masalah adalah jenis berpikir kompleks yang menggunakan sejumlah keterampilan yang berurutan untuk memecahkan masalah. Berpikir Kreatif adalah jenis berpikir kompleks yang menghasilkan gagasan baru dan orisinal (Udall \& Daniels, 1991). Untuk pengertian keterampilan berpikir kompleks, F.J. King dkk. memberi istilah dengan keterampilan berpikir tinggi (higher order thinking skills), yang meliputi berpikir kritis, logis, reflektif, metakognitif, dan kreatif. Keterampilan-keterampilan berpikir tingkatan tinggi tersebut akan muncul ketika seseorang dihadapkan pada permasalahan atau pertanyaan yang tidak biasa, tidak berkepastian, dan dilematis. Keberhasilan penggunaan keterampilan tersebut terlihat dari suatu penjelasan, pengambilan keputusan, unjuk kerja, dan produkproduk sesuai konteks pengetahuan dan pengalaman yang dimilikinya.

\section{Jenis Keterampilan Berpikir Kompleks}

Sejak lama Taxonomy of Educational Objectives dari Bloom dipandang kurang sesuai lagi, sehingga Lorin dan kawan-kawan melakukan revisi terhadap taxonomy tersebut dengan memasukkan kemampuan berpikir kreatif. Berikut Tabel 1 memuat taxonomy Bloom yang sudah direvisi yang memuat keterampilan berpikir dari tingkat paling sederhana (remember) hingga paling kompleks (create).

Tabel 1. Taxonomy Bloom

\begin{tabular}{|c|c|}
\hline Categories & cognitive process \\
\hline \multirow[t]{2}{*}{ 1. REMEMBER } & 1.1. Recognizing \\
\hline & 1.2. Recalling \\
\hline \multirow[t]{7}{*}{ 2. UNDERSTAND } & 2.1. Interpreting \\
\hline & 2.2. Exemplifying \\
\hline & 2.3. Classifying \\
\hline & 2.4. Summarizing \\
\hline & 2.5. Inferring \\
\hline & 2.6. Comparing \\
\hline & 2.7. Explaining \\
\hline \multirow[t]{2}{*}{ 3. $A P P L Y$} & Executing \\
\hline & 3.2. Implementing \\
\hline \multirow[t]{3}{*}{ 4. $A N A L Y Z E$} & 4.1. Differentiating \\
\hline & 4.2. Organizing \\
\hline & 4.3. Attributing \\
\hline \multirow[t]{2}{*}{ 5. EVALUATE } & Checking \\
\hline & Critiquing \\
\hline \multirow[t]{3}{*}{ 6. CREATE } & 6.1. Generating \\
\hline & 6.2. Planning \\
\hline & 6.3. Producing \\
\hline
\end{tabular}

Sumber: The Cognitive Process Dimension (Anderson et al, 2001)

Berdasarkan taxonomy tersebut di atas kategori Remember, Understand, dan Apply termasuk kemampuan berpikir rendah atau sederhana, sedangkan kategori Analyze, Evaluate, dan Create termasuk kemampuan berpikir tinggi atau kompleks.

Acuan lain yang sering diikuti untuk merancang tugas-tugas untuk membangun dan mengembangkan keterampilan berpikir kompleks adalah Matrix Gubbin seperti pada Tabel 2. Matrix Gubbin ini memuat rincian keterampilan berpikir kompleks untuk jenis Berpikir Kritis, Pemecahan Masalah, dan Berpikir Kreatif serta contoh keterampilan Metakognitif.

Melihat bentuk-bentuk tugas/kegiatan berpikir kompleks seperti diuraikan di atas, tentunya cara belajar yang pasif - yang berpusat pada guru, banyak latihan menjawab soal-soal pengetahuan dan pemahaman - tidak akan mampu membangun dan mengembangkan keterampilan berpikir anak hingga mencapai tingkatan 


\section{Berpikir Kritis}

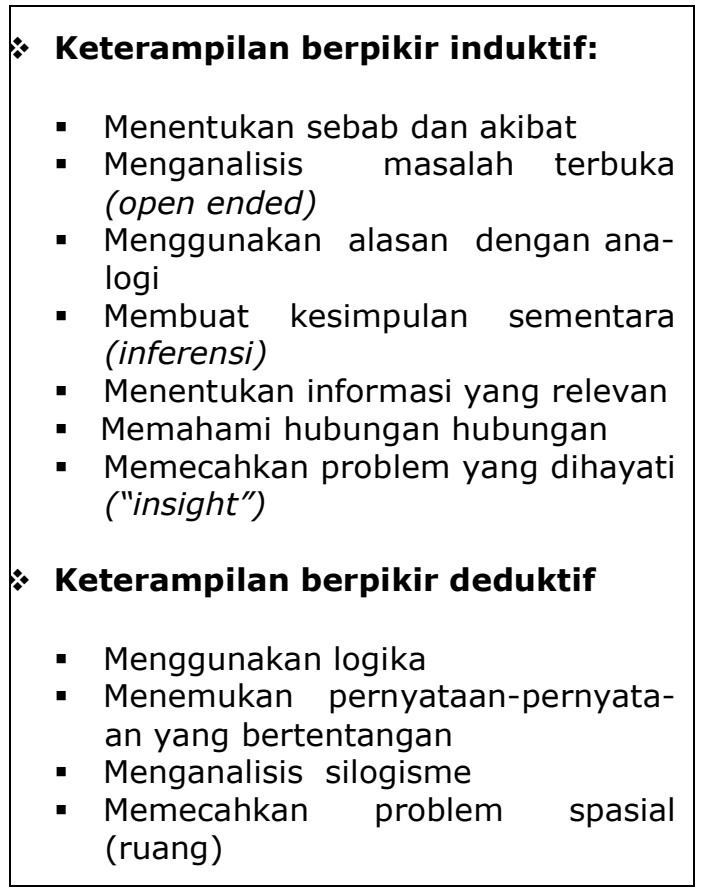

\section{* Keterampilan berpikir evaluative}

- Membedakan antara fakta dan opini

- Menilai kredibilitas suatu sumber

- Mengamati dan menilai laporan hasil observasi

- Mengidentifikasi isu dan problem utama

- Memahami asumsi yang mendasarinya

- Mendeteksi bias, stereotip dan klise

- Mengenal bahasa yang terlalu berlebihan

- Menilai hipotesis

- Mengklasifikasi data

- Memprediksi konsekuensi

- Mendemonstrasikan urutan sintesis informasi

- Merencanakan alternatif strategi

- Mengenal ketidak-ajegan informasi

- Mengidentifikasi alasan yang dikemukan dan yang tidak

- Membandingkan persamaan dan perbedaan

- Menilai argumen

\section{Pemecahan Masalah}

- Mengidentifikasi problem umum

- Mengklarifikasi problem

- Merumuskan pertanyaan yang tepat

- Merumuskan alternatif pemecahan masalah

- Memilih solusi yang terbaik
- Memonitor penerimaan solusi

- Menarik kesimpulan

- Menghasilkan gagasan-gagasan yang bertalian

- Merumuskan hipotesis

- Menerapkan solusi

\section{Berpikir Kreatif}

- Membuat daftar atribut objek/situasi
$\begin{aligned} & \text { Menghasilkan gagasan yang beragam } \\ & \text { (kelancaran) }\end{aligned}$ $\begin{aligned} & \text { - Menghasilkan gagasan yang unik (originalitas) } \\ & \text { - Mensintesis laporan. } \\ & \begin{array}{l}\text { Menghasilkan gagasan gagasan yang } \\ \text { berbeda (fleksibilitas) }\end{array}\end{aligned}$

Tabel 2. Gubbin's Matrix of Thinking Skills (Udall \& Daniels, 1991)

kompleks. Proses pembelajaran yang memungkinkan adalah yang melibatkan anak secara aktif, baik fisik maupun mental. Anak diberi kesempatan yang banyak untuk berinteraksi, seperti bertanya, mempertanyakan, memberi pendapat, mengungkapkan gagasan, mengekspresikan diri melalui karya-karyanya. Kreativitas anak akan berkembang melalui tugastugas yang mengasah keterampilan berpikir kompleks. Jindrich (2005) berpendapat bahwa kecerdasan anak banyak berkembang melalui aktivitas-aktivitas, seperti: pemecahan masalah dan penalaran, pembentukan konsep, peniruan/ memori, atau asosiasi/klasifikasi. Untuk menumbuhkan kreativitas anak prasekolah, Jindrich menyarankan kegiatan-kegiatan, diantaranya seperti berikut: bertanya dengan pertanyaan terbuka, beri anak banyak pilihan, mengulang cerita, mengarang cerita, permainan kata, bermain dengan menggunakan boneka, 
minta pendapat mereka tentang sesuatu.

Menurut De Bono (1991), kreativitas dapat ditumbuhkan melalui berpikir lateral (lateral thinking), sebagai proses penggunaan informasi untuk menumbuhkan kreativitas dan pem-bangunan kembali pemahaman (insight restructuring)). Berpikir lateral berhubungan erat dengan kreativitas, yang meliputi pembangunan kembali, pencarian jalan keluar, dan perangsangan pola baru. Berpikir lateral berperan dalam melepaskan diri dari gagasan lama dan merangsang terhadap gagasan baru. Proses berpikir lateral ini berlaku untuk semua umur dan semua tingkat pengetahuan yang berbeda-beda. Permasalahan yang sederhana dapat digunakan untuk semua kelompok usia. Bagi kelompok usia muda bentuk visual jauh lebih efektif dibandingkan dengan bentuk verbal, sebab anak lebih cepat memahami sesuatu yang dijelaskan secara visual dan menyatakan sesuatu secara visual.

Dengan demikian, bakat kreatif yang sudah dianugerahkan sejak anak lahir, akan berkembang terus hingga dewasa. Anak akan bertumbuh menjadi insan kreatif dengan daya kreasi dan daya cipta, punya kemampuan menjadikan barang kurang berharga menjadi bernilai ekonomis.

Keterampilan berpikir tinggi dibangun atas dasar keterampilan berpikir rendah atau sederhana, seperti cognitive strategies, comprehension, concept classification, discriminations, routine rule using, simple analysis, simple application (King $d k k$.). Menurut taxonomy Bloom yang sudah direvisi, kemampuan berpikir sederhana termasuk remember, understand, dan apply (Anderson, L.W. et al., 2001, A Taxonomy for Learning Teaching and Assessing) Strategi pembelajaran dan lingkungan belajar yang tepat akan membangun dan menumbuhkan kemampuan berpikir tinggi. Scaffolding yaitu memberikan dukungan atau bantuan secukupnya kepada peserta didik pada awal pelajaran dan secara bertahap memberikan kesempatan pada mereka untuk bekerja mandiri, diyakini King dkk. bisa membantu anak mengembangkan keterampilan berpikir kompleks mereka. Kegiatan-kegiatan dalam kelompok kecil, seperti student discussions, peer tutoring, dan cooperative learning bisa efektif dalam mengembangkan keterampilan berpikir anak. Kegiatan pembelajaran dan penilaian sebaiknya banyak melibatkan siswa dengan tugas-tugas yang menantang dan guru memberikan umpan balik selama proses pembelajaran berlangsung (King, dkk. tanpa tahun).

\section{Metodologi Penelitian}

Terdapat 3 jenis penelitian, yakni: 1) Exploratory research, yaitu penelitian yang bertujuan untuk mencari kejelasan suatu masalah; 2) Descriptive research, yaitu penelitian yang bertujuan untuk mencari deskripsi suatu objek; dan 3) Explanatory research, yaitu penelitian yang bertujuan untuk mengetahui kejelasan hubungan atau menguji hipotesis. Untuk mendapatkan data tentang kemampuan TPK dalam merancang kegiatan pembelajaran dan penilaian bermuatan keterampilan berpikir kompleks. Maka jenis penelitian yang digunakan dalam studi ini adalah descriptive research dengan metode survai. Survai dilakukan dengan meminta responden merancang suatu tugas atau kegiatan pembelajaran dan penilaian yang dapat mengembangkan keterampilan berpikir kompleks peserta didik. Tugas atau kegiatan yang dirancang oleh responden selanjutnya dikaji dengan mengacu kepada The Cognitive Process Dimension dan Gubbin's Matrix of Thinking Skills di atas. Pengkajian tersebut dilakukan untuk menentukan apakah tugas atau kegiatan yang dirancang responden dapat mengembangkan keterampilan berpikir kompleks atau tidak.

\section{Sampel dan Data}

Penelitian dilakukan di empat kabupaten, yaitu Kabupaten MT (Provinsi Maluku), Kabupaten B (Provinsi Kalimantan Timur), Kabupaten RH (Provinsi Riau), dan Kabupaten LB (Provinsi NTB) pada tahun 2009 dan 2010. Adapun Sampel penelitian adalah Tim Pengembang Kurikulum (TPK) yang namanya ada pada SK, sedikitnya dari Kepala Dinas Pendidikan Kabupaten/Kota. TPK tersebut bekerja di satuan pendidikan TK, SD, SMP, SMA, SMK, dan SLB yang mengajar mata pelajaran berbeda di kelas yang berbeda. Berdasarkan kelengkapan data, diperoleh 118 TPK yang dapat dijadikan sampel penelitian dari empat kabupaten. Latar belakang satuan pendidikan tidak dibedakan, karena menurut peraturan yang berlaku, tenaga pendidik dan tenaga kependidikan yang dipilih sebagai TPK dianggap punya kemampuan untuk 
menyusun KTSP dan men-sosialisasikannya ke sekolah-sekolah.

\section{Teknik Pengumpulan Data}

Untuk mengumpulkan data kemampuan TPK merancang tugas atau kegiatan pembelajaran dan penilaian bermuatan keterampilan berpikir kompleks digunakan teknik non tes. Hal ini dilakukan dengan cara menugaskan setiap TPK merancang satu tugas atau kegiatan pembelajaran dan penilaian bermuatan keterampilan berpikir kompleks yang biasa diberikan kepada peserta didik mereka di sekolah, sesuai mata pelajaran yang dikuasai.

\section{Teknik Analisis Data}

Data yang telah terkumpul selanjutnya dianalisis dengan cara deskriptif. Tugas atau kegiatan yang dirancang TPK dianalisis berdasarkan Tabel The Cognitive Process Dimension yang memuat keterampilan berpikir dari yang paling sederhana hingga paling kompleks dan Gubbin's Matrix of Thinking Skills yang memuat hanya keterampilan berpikir kompleks. Apabila tugas yang dirancang memuat kemampuan berpikir kompleks seperti yang ada pada ke dua tabel, maka dapat dikatakan tugas tersebut sesuai untuk keterampilan berpikir kompleks. Sebaliknya, apabila tugas yang dirancang TPK tidak memuat kemampuan berpikir kompleks seperti yang ada pada ke dua tabel, maka tugas tersebut dapat dianggap bermuatan kemampuan berpikir sederhana atau rendah.

\section{Hasil Penelitian dan Pembahasan \\ Kemampuan TPK kabupaten dalam merancang kegiatan pembelajaran dan penilaian ber- muatan keterampilan berpikir kompleks}

Berdasarkan data yang diperoleh dari empat kabupaten, pada umumnya responden merancang tugas atau kegiatan pembelajaran dan penilaian bermuatan kemampuan-kemampuan berpikir seperti pada Tabel 3. Selain memuat informasi tentang kemampuan berpikir yang dirancang TPK, tabel tersebut juga menyajikan informasi jumlah responden yang merancang kemampuan berpikir tersebut .
Tabel 3. Kemampuan Berpikir yang Dirancang Responden

\begin{tabular}{|c|c|c|}
\hline Categories & $\begin{array}{l}\text { Cognitive } \\
\text { process }\end{array}$ & $\begin{array}{l}\text { Jumlah } \\
\text { responden }\end{array}$ \\
\hline \multirow[t]{3}{*}{ REMEMBER } & Recognizing & 9 \\
\hline & Recalling & 24 \\
\hline & & $=33=$ \\
\hline \multirow[t]{8}{*}{ UNDERSTAND } & Interpreting & 10 \\
\hline & Exemplifying & - \\
\hline & Classifying & 5 \\
\hline & Summarizing & - \\
\hline & Inferring & 4 \\
\hline & Comparing & 18 \\
\hline & Explaining & 4 \\
\hline & & $=51=$ \\
\hline \multirow[t]{3}{*}{ APPLY } & Executing & - \\
\hline & Implementing & 5 \\
\hline & & - \\
\hline \multirow[t]{4}{*}{ ANALYZE } & Differentiating & 9 \\
\hline & Organizing & - \\
\hline & Attributing & 5 \\
\hline & & $=14=$ \\
\hline \multirow[t]{3}{*}{ EVALUATE } & Checking & 2 \\
\hline & Critiquing & 4 \\
\hline & & $=6=$ \\
\hline \multirow[t]{4}{*}{ CREATE } & Generating & 1 \\
\hline & Planning & 1 \\
\hline & Producing & 7 \\
\hline & & $=9=$ \\
\hline TOTAL & \multicolumn{2}{|l|}{$\begin{array}{l}\text { Higher Order }=\mathbf{2 9} \\
\text { Lower Order }=\mathbf{8 9}\end{array}$} \\
\hline
\end{tabular}

Apabila kemampuan-kemampuan yang ada pada daftar di atas dibandingkan dengan ke dua tabel di atas, dapat diketahui bahwa tugas-tugas pembelajaran dan penilaian yang dirancang responden banyak yang bermuatan keterampilan berpikir rendah atau sederhana. Dari 118 responden hanya 29 orang $(24.58 \%)$ yang mampu merancang tugas bermuatan kemampuan berpikir kompleks, selebihnya 89 orang (75.42\%) mampu merancang kemampuan berpikir sederhana atau rendah. Untuk kemampuan berpikir paling kompleks atau tinggi, yaitu Berpikir Kreatif, hanya 9 orang (31\%) dari 29 responden yang mampu merancang. Yang mengejutkan adalah, dari 89 responden ternyata 33 orang (37.1\%) merancang tugas bermuatan kemampuan berpikir yang paling rendah atau mendasar, yaitu Berpikir Remember. Jumlah ini termasuk cukup banyak jika dibandingkan dengan jumlah responden yang mampu merancang berpikir kompleks. Kondisi ini cukup mencemaskan, mengingat tugas yang diminta dirancang adalah tugas yang sudah biasa mereka 
berikan selama ini kepada peserta didik mereka. Dari data ini dapat dikatakan bahwa kemampuan kreatif siswa kurang dibangun dan dikembangkan, padahal daya kreasi dan daya cipta yang dikehendaki pada tujuan pendidikan nasional dan Instruksi Presiden dibangun dan dikembangkan dari berpikir kompleks tersebut.

Data ini menunjukkan bahwa sebagian besar TPK yang juga adalah guru, kepala sekolah dan pengawas selama ini belum maksimal berusaha meningkatkan kompetensi mereka dalam melaksanakan proses pembelajaran dan penilaian yang bermutu, dan pada akhirnya berdampak pada kualitas peserta didik.

\section{Keterbatasan Penelitian}

Walaupun penelitian telah diupayakan seoptimal mungkin, namun disadari adanya beberapa keterbatasan yaitu: 1) Penelitian dilakukan hanya pada empat kabupaten. Hal ini disebabkan oleh keterbatasan waktu dan tenaga. Sebaiknya penelitian dilanjutkan dengan jumlah kabupaten yang lebih banyak; 2) Jumlah sampel yang diperoleh 118. Hal ini disebabkan antara lain data yang diperoleh kurang lengkap; dan 3) Tugas atau kegiatan pembelajaran dan penilaian yang diminta hanya satu, sehingga belum menjamin dapat mengungkap kemampuan TPK dalam merancang tugas atau kegiatan bermuatan keterampilan berpikir kompleks.

\section{Simpulan dan Saran Simpulan}

Berdasarkan hasil penelitian terhadap 118 TPK di empat kabupaten, dapat diketahui bahwa pada umumnya TPK belum mampu membangun dan mengembangkan kemampuan berpikir kompleks atau berpikir tinggi peserta didik melalui kegiatan pembelajaran dan penilaian yang mereka rencanakan. Dari segi jumlahpun hanya $24.58 \%$ TPK yang mampu merancang tugas untuk kemampuan berpikir kompleks tersebut dan dari jumlah yang sedikit ini hanya segelintir yang mampu merancang tugas berpikir kreatif. Sebaliknya, dari tugas yang dirancang sebagian besar TPK hanya mampu mengembangkan kemampuan berpikir sederhana atau rendah. Dengan demikian dapat dikatakan, selama ini mungkin mereka belum mengembangkan potensi dan bakat kreatif peserta didik mereka melalui proses pembelajaran dan penilaian yang mereka laksanakan. Di samping Sebagai TPK sebagian dari mereka juga guru, pengawas, dan kepala sekolah yang tentunya banyak mengurusi proses pembelajaran di kelas. Apabila kondisi ini berlangsung berlarut-larut dapat diramalkan potensi kreatif anak yang dibawa sejak lahir akan terpendam dan akhirnya akan hilang setelah usia 15 tahun.

Jumlah responden pada penelitian ini memang hanya 118 TPK dari 4 kabupaten, namun jumlah yang sangat terbatas ini dapat dijadikan petunjuk bahwa kondisi TPK dari kabupaten lain kemungkinan tidak jauh berbeda. Hasil penelitian ini memberi tanda bahwa kompetensi TPK secara keseluruhan yang meliputi semua kabupaten/kota di Indonesia masih jauh dari harapan bahwa mereka mampu dan dapat diandalkan untuk menjalankan peran mereka sebagai pendamping atau fasilitator bagi satuan pendidikan di wilayah binaan mereka. Sebagai TPK mereka seharusnya dapat diandalkan untuk memberikan pelatihan pengembangan kurikulum bagi satuan pendidikan dan mampu memberikan layanan dan konsultasi kurikulum dan pembelajaran bagi pihak yang membutuhkan.

Dapat dikatakan peran TPK sangat besar dalam meningkatkan mutu pendidikan di wilayah binaannya. Oleh karena itu yang menjadi TPK adalah tenagatenaga pilihan yang dinilai punya kemampuan dan kelebihan dibandingkan kebanyakan tenaga pendidik dan kependidikan di wilayahnya. Seharusnya kondisi seperti ini tidak terjadi. Kemungkinan lainnya, sebenarnya mereka belum sepenuhnya memahami tentang keteram-pilan berpikir dan belum mampu memisahkan menurut tingkatannya (higher order atau lower order) seperti yang diuraikan pada bab 2, sehingga tidak mampu untuk menerapkan di kelas. Menurut informasi mereka sudah sering mendengar tentang taxonomy Bloom dan bila dipertanyakan mereka biasanya menjawab sudah tahu dan paham. Kelihatannya pernyataan seperti itu tidak bisa sepenuhnya diterima tapi sebaiknya dibuktikan. Karena itu, dipandang perlu untuk menata kembali TPK yang sudah dibentuk, baik di tingkat provinsi maupun kabupaten/kota, untuk lebih ditingkatkan lagi kemampuan mereka agar 
lebih layak menjadi tim pengembang kurikulum yang handal membantu tugas dinas pendidikan di wilayah yang bersangkutan.

\section{Saran}

Peran TPK sangat penting dalam meningkatkan kualitas pendidikan di wilayah mereka. Selain membantu dan mendampingi satuan pendidikan membuat kurikulum, TPK juga tempat konsultasi bagi satuan pendidikan bila menemukan masalah dalam mengembangkan kurikulum dan pembelajaran. Oleh karena itu, seharusnya yang menjadi TPK adalah individu-individu pilihan dan memiliki kompetensi yang tinggi sehingga diharapkan mampu membantu dinas pendidikan melaksanakan tugasnya membina satuan pendidikan di wilayah yang bersangkutan.

Namun demikian, hasil penelitian menunjukkan hal sebaliknya bahwa sebagian besar TPK tidak mampu merancang tugas pembelajaran dan penilaian untuk membangun dan mengembangkan kemampuan berpikir kompleks atau tinggi. Karena itu, penataan kembali TPK yang sudah dibentuk baik di tingkat provinsi maupun di tingkat kabupaten/kota sudah menjadi kebutuhan yang mendesak, mengingat pelaksanaan KTSP sudah berjalan beberapa tahun.

Untuk meningkatkan mutu TPK diusulkan beberapa saran seperti berikut ini. Pertama, TPK yang sudah dibentuk dihimbau untuk tidak diganti sekurang-kurangnya selama tiga tahun. Hal ini dimaksudkan agar pembinaan terhadap TPK yang sama dapat berjalan secara berkesinambungan. Selama ini himbauan beserta alasannya sudah disampaikan kepada pihak dinas pendidikan provinsi maupun kabupaten/kota, baik melalui surat dinas maupun pada pertemuan rapat koordinasi (rakor) kepala-kepala dinas pendidikan seluruh provinsi dan seluruh kabupaten/kota, yang biasanya diselenggarakan pada setiap awal tahun sebelum program bimbingan teknis atau bantuan profesional dilaksanakan. Namun, cara ini kurang berhasil karena ada salah pengertian dari pihak dinas pendidikan yang ingin melakukan pemerataan kesempatan pembinaan dikalangan tenaga pendidik dan kependidikan. Karena itu, disarankan agar pihak yang menyelenggarakan bimbingan teknis/bantuan professional meyakinkan gubernur atau bupati/walikota yang akan dikunjungi betapa pentingnya peran TPK diwilayah mereka. Mereka layak diyakini karena mereka yang membentuk dan mengangkat TPK di wilayah yang bersangkutan. Kedua, mengundang petugas dari kantor gubernur pada waktu rapat koordinasi kepala dinas kabupaten/kota, sehingga muncul 'sense of belonging ' dari pihak gubernur terhadap TPK di wilayahnya. Ketiga, meninjau kembali materi bimbingan teknis dan pendampingan TPK provinsi dan kabupaten/kota yang selama ini dilaksanakan, baik oleh Pusat Kurikulum maupun oleh lembagalembaga lainnya yang juga melaksanakan kegiatan yang sejenis. Sesuai tugas dan fungsinya, TPK provinsi seharusnya membina TPK kabupaten/kota. Penataan kembali materi bimbingan teknis tersebut ditinjau dari urutan prioritas, dilihat dari kepentingan anak dan satuan pendidikan dan waktu yang tersedia. Memang banyak materi yang ingin diberikan dengan anggapan semuanya diperlukan. Karena itu materi perlu ditata sesuai urutan prioritas dengan mempertimbangkan hal-hal berikut: 1 ) materi yang sangat perlu dan terkait langsung dengan proses pembelajaran, sehingga perlu disajikan dan didiskusikan bersama; 2) materi yang membutuhkan waktu agak banyak untuk latihan; 3) materi yang bisa dipelajari dan dikuasai melalui membaca soft copy yang disediakan. Keempat, materi bisa dibagikan pada waktu rapat koordinasi dengan kepala dinas dari provinsi dan kabupaten/ kota yang akan dikunjungi, selanjutnya materi mereka teruskan kepada TPK. Dengan begitu, sebelum bimbingan teknis dilaksanakan diharapkan TPK sudah membaca dan mempelajari materi. Apa yang ingin mereka diskusikan lebih dalam bisa dilakukan ketika bimbingan teknis berlangsung. Kelima, meningkatkan kompetensi petugas dari pusat yang akan menjadi fasilitator pada kegiatan bimbingan teknis, sehingga materi yang akan disampaikan sudah dikuasai sepenuhnya, baik dari segi substansi maupun metode penyampaian. Dengan terpenuhinya saran-saran tersebut di atas pelaksanaan bimbingan teknis dan bantuan professional terhadap TPK diharapkan dapat berlangsung lebih bermutu dan efektif, yang pada akhirnya membantu pihak satuan pendidikan dalam meningkatkan kualitas lulusannya. 


\section{Pustaka Acuan}

Anderson, L.W., Krathwohl, D.R. 2001. A Taxonomy for Learning, Teaching and Assessing - A Revision of Bloom's Taxonomy of Educational Objectives. New York: Longman

De Bono, Edward. 1991. Lateral Thinking, Creativity Step by Step. New York: Harper \& Row, Publishers

Instruksi Presiden Republik Indonesia Nomor 6 Tahun 2009 tentang Pengembangan Ekonomi Kreatif. Jindrich, Susan. 2005. How to Help Children Learn. Bookmarks

King, F.J., Goodson, L., Rohani, L. Higher Order Thinking Skills. The Center for Advancement of Learning and Assessment. www.cala.fsu.edu

Peraturan Menteri Pendidikan Nasional Republik Indonesia Nomor 41, Tahun 2007 Tentang Standar Proses Untuk Satuan Pendidikan Dasar dan Menengah

Peraturan Menteri Pendidikan Nasional Republik Indonesia Nomor 22, Tahun 2006 Tentang Standar Isi Untuk Satuan Pendidikan Dasar dan Menengah

Peraturan Menteri Pendidikan Nasional Republik Indonesia Nomor 23, Tahun 2006 Tentang Standar Kompetensi Lulusan Untuk Satuan Pendidikan Dasar dan Menengah

Peraturan Pemerintah Republik Indonesia Nomor 19 Tahun 2005 Tentang Standar Nasional Pendidikan.

Pusat Kurikulum. 2007. Model Jaringan Kurikulum. Kementerian Pendidikan Nasional, Jakarta.

Surat Edaran Menteri Pendidikan Nasional Nomor 33/2007 Tentang Sosialisasi Kurikulum Tingkat Satuan Pendidikan. Tanggal 13 Februari 2007.

Udall, A.J. and Daniels, J.E. 1991. Creating the Thoughtful Classroom. Zephyr Press

Undang-Undang Republik Indonesia Nomor 20, Tahun 2003, Tentang Sistem Pendidikan Nasional. 